PAEDAGogia CHRISTIANA

$1 / 25$ (2010) - ISSN 1505-6872

Marlena Grzelak-Klus*

Warszawa

\title{
Doświadczania dialogu w edukacji i życiu społecznym - możliwości i ograniczenia III Ogólnopolska Konferencja Pedagogiki Dialogu, Warszawa, 6 listopada 2009 roku
}

Dnia 6 listopada 2009 roku w Akademii Pedagogiki Specjalnej im Marii Grzegorzewskiej w Warszawie odbyła się III Ogólnopolska Konferencja Pedagogiki Dialogu, którą tym razem zorganizowano wokół zagadnienia: Doświadczania dialogu w edukacji i życiu społecznym - możliwości i ograniczenia. III Konferencja Pedagogiki Dialogu stanowi kontynuację podjętego przed trzema laty dzieła integracji środowiska osób zainteresowanych dialogowaniem oraz wymianą praktycznych i teoretycznych doświadczeń dialogowania tak w relacjach osobowych, jak i w przestrzeniach publicznych.

Owocem dotychczasowych spotkań konferencyjnych są publikacje wystąpień zebrane w roku 2007 w tom zatytułowany: Pedagogika dialogu. Dialog warunkiem rozwoju osobowego i społecznego, a w roku $2008 \mathrm{w}$ tom pod tytułem Pedagogika dialogu. Dialog w teorii i praktyce edukacyjnej, zredagowane przez E. Dąbrowę i D. Jankowską, a wydane przez Wydawnictwo APS w Warszawie.

Trzecie spotkanie pedagogów dialogu skupiło uwagę uczestników na problemach poszukiwania możliwości doświadczania otwartych i dialogowych relacji międzyludzkich usytuowanych w obszarach aktywności społecznej, w tym także w przestrzeniach edukacyjnych. Ważnym staje się przy tym namysł nad uwarunkowaniami ograniczającymi dialog w edukacji i ży-

* Mgr Marlena Grzelak-Klus, doktorantka w Instytucie Pedagogiki Akademii Pedagogiki Specjalnej im. Marii Grzegorzewskiej w Warszawie. 
ciu społecznym. Rozumienie dialogu jako doświadczenia egzystencjalnego i edukacyjnego zarazem otworzyło rozważania konferencyjne na problematykę wzajemnych powiązań dialogu i poznania, rozumienia siebie i świata, kształtowania się ludzkiej tożsamości, budowania życia rodzinnego, reformowania edukacji szkolnej, kształcenia akademickiego czy też życia społecznego przejawiającego się w różnych formach i odmianach.

6 listopada 2009 roku o godzinie $10^{00}$ Jego Magnificencja Rektor Akademii Pedagogiki Specjalnej, prof. dr hab. Jan Łaszczyk, uroczyście otworzył plenarne obrady III Ogólnopolskiej Konferencji Pedagogiki Dialogu, poświęcone księdzu prof. dr hab. Januszowi Tarnowskiemu w rocznicę dziewięćdziesiątych urodzin. Szacowny Jubilat, twórca i praktyk pedagogiki dialogu, ze wzruszeniem wysłuchał i obejrzał ilustrowane zdjęciami z lat dzieciństwa, młodości i z lat dojrzałych wspomnienia ważnych momentów życiowych i zawodowych oraz przyjął podziękowania za twórczy wkład w rozwój pedagogiki dialogu. Z uwagą wysłuchał również wykładu wygłoszonego przez prof. dr hab. Bogusława Milerskiego poświęconego Pedagogowi dialogu, jego wartości i roli, którą pełni jako mistrz w relacji $\mathrm{z}$ wychowankiem. $Z$ dużym zainteresowaniem przysłuchiwał się sprawozdaniu z praktycznych zastosowań założeń pedagogiki dialogu swojego autorstwa w tworzeniu i rozwoju koncepcji szkół ALA oraz koncepcji tutoringu rozwojowego, opartego o bezpośredni i indywidualny kontakt ucznia i wychowawcy w atmosferze szanującej godność, człowieczeństwo, wzajemność relacji i doświadczania wspólnej rzeczywistości życiowej przez ucznia i wychowawcę. Sprawozdanie złożył na ręce profesora Tarnowskiego mgr Mariusz Budzyński nauczyciel i tutor wrocławskich szkół ALA. Pierwszą część obrad plenarnych zakończył sam Jubilat, który z właściwym sobie humorem i życzliwością wobec ludzi opowiedział o tym: czym - dla niego - jest pedagogika dialogu? Wspomnienia, refleksje, a także spotkania z profesorem Januszem Tarnowskim przeniosły się w kuluary, gdzie przy kawie i herbacie ksiądz Tarnowski podpisywał swoje książki i odpowiadał na pytania zgromadzonych wokół niego innych/młodszych pedagogów dialogu.

Drugą część obrad plenarnych zainaugurowała prof. dr hab. Joanna Rutkowiak, analizując Spoleczne warunki dialogowania w neoliberalnej kulturze indywidualizmu. Opierający się na ideach wolności, równości, autentyczności czy emancypacji i osadzony w życiu wspólnotowym indywidualizm liberalny autorka postrzega jako przestrzeń umożliwiającą i sprzyjającą otwartym i dialogowym relacjom międzyludzkim. Zagrożeniem dla dialogu - zdaniem profesor Rutkowiak - stają się natomiast obserwowane we współczesnej kulturze tendencje neoliberalnego indywidualizmu, który jako wyraz subkultury prokonsumenckiej nastawiony jest na nieustanne konsumowanie, dbanie o własne interesy i nieograniczoną swobodę wyboru. 
Taki konsumencki egoizm wyraźnie uwidacznia się w centralnie zarządzanej edukacji, osłabiającej podmiotowe usytuowanie wychowawcy i wychowanka w strukturach systemowych, a nastawionej na tak zwany „bieg edukacyjny” czy „czuwanie nad sobą". Wyłączna troska o własne zdrowie fizyczne i psychiczne, własną urodę i kondycję, własny rozwój i własne cele życiowe, z pola widzenia usuwa poczucie wspólnoty i jej dobra. Grupa/społeczność jest tu tylko trampolina, od której warto się oderwać/odbić, aby odnieść sukces niekończącego się konsumowania świata.

Drugi głos w dyskusji plenarnej dotyczył Doświadczania dialogu w tworzeniu wiedzy pedagogicznej. Wykład księdza prof. dr hab. Mariana Nowaka usystematyzował wiedzę zebranych na temat doświadczenia i dialogu jako źródła poznania rzeczywistości, w tym także rzeczywistości pedagogicznej. Wypływająca z doświadczenia dialogowego wiedza pedagogiczna, w przekonaniu autora, stanowi w dzisiejszej pedagogice cenne, bo praktyczne, źródło, które inspiruje różnorodne, a przede wszystkim aktualne refleksje typu pedagogicznego.

Kolejna referentka, prof. dr hab. Urszula Ostrowska, zajęła się tematyką Uczelni wyższej jako przestrzeni doświadczania dialogu. Traktując przestrzeń akademicką jako wspólnotę relacyjną zawiązaną pomiędzy wszelkimi obiektami społecznie i kulturowo przypisanymi/osadzonymi w środowisku akademickim, szczególną uwagę zwróciła na relacje nauczycieli akademickich i studentów. Dialog, toczący się pomiędzy nimi w czasoprzestrzeni akademickiej, wsparty jest dzisiaj wiedzą o dialogowaniu czy też bywa nakierowywany na nowe cele, zadania i wyzwania, stawiane przed wspólnotami akademickimi, ale przecież nadal najważniejsze są w nim - zdaniem profesor Ostrowskiej - uwarunkowane wielowiekowymi doświadczeniami dialogowymi relacje typu: mistrz-uczeń, mentor/przewodnik-osoba prowadzona.

Następna referentka dr Ewa Lewandowska-Tarasiuk przeanalizowała kondycję Języka dialogu w przestrzeni publicznej, uwzględniając przede wszystkim wypowiedzi prezentowane przez media i polityków. Wskazując na model debaty oxfordzkiej, autorka postulowała o powszechną edukację językową umożliwiającą komunikację wspólnotową.

Prof. dr hab. Maciej Biała jako filozof religii przyjrzał się Możliwościom dialogu religijnego $w$ świecie wspótczesnym. Wskazując zagrożenia, które płyną tak z fundamentalizmów religijnych, jak i z pluralizmu światopoglądowego, to właśnie egalitaryzm pesymistyczny uznał za źródło szczególnego zagrożenia dla wolności religijnej oraz dla dialogu międzyreligijnego. Takie postawienie sprawy wzbudziło ożywioną dyskusję uczestników konferencji i trudno było zakończyć obrady drugiej części sesji plenarnej.

Około godziny $15^{30}$ rozpoczęły się obrady w trzech sekcjach tematycznych oraz w panelu dyskusyjnym, poświęconym możliwościom/niemożno- 
ściom obecności dialogu w przestrzeniach społecznych, szkolnych i akademickich. Sekcje tematyczne zorganizowane były wokół następujących zagadnień problemowych:

1) I Sekcja, prowadzona przez księdza prof. dr hab. Mariana Nowaka i dr Jarosława Garę, zajęła się Doświadczeniem dialogu w refleksji filozoficznej i przeżyciu egzystencjalnym. W toku przemyśleń nad egzystencjalnym doświadczaniem dialogu postawiono szereg istotnych dla człowieka XXI wieku pytań:

- o rolę dialogu i jego doświadczania w rozumieniu osoby i kształtowaniu jej tożsamości pytali dr Grażyna Lubowiecka i dr Andrzej Ryk;

- o specyfikę doświadczeń dialogowych pytali dr Jarosław Gara i dr Janusz Maj;

- o znaczenie samotności i osamotnienia w ludzkim dialogowaniu ze sobą zapytała dr Sabina Zalewska;

- o kulturowe tendencje wzmacniające narcyzm dopytała dr Bożena Tołwińska;

- o rolę kompetencji emocjonalnych w doświadczaniu dialogu pytała dr Katarzyna Szoc;

- o możliwość dialogowania z maszyną zapytał mgr Piotr Orzeszek.

2) II Sekcja, animowana przez dr Ewę Dąbrowę, skoncentrowała się na Doświadczeniu dialogu w życiu społecznym, a głosy referentów oscylowały wokół trzech grup problemowych związanych z problemami konkretnych grup społecznych to jest:

- brak dialogu $\mathrm{w}$ rodzinie i w relacjach dziecko-rodzic podnosili mgr Monika Czerw, dr Elżbieta Bednarz, dr Matylda Gwoździcka-Piotrowska, dr Dominika Czajkowska-Ziobrowska oraz dr Przemysław Gąsiorek;

- drogi i bezdroża dialogu w placówkach wychowawczych, terapeutycznych i opiekuńczych omawiały mgr Katarzyna Bogusz-Żebrowska, dr Elena Karpuszenka i dr Edyta Nieduziak;

- warunki budowania dialogu w przestrzeniach publicznych rozważały dr Agnieszka Łagoda, dr Ewa Dąbrowa oraz dr Halina Postek.

3) III Sekcja, poprowadzona przez prof. dr hab. Urszulę Ostrowskąi dr Dorotę Jankowska, przyglądała się Doświadczeniu dialogu w edukacji. W dyskusji uczestnicy koncentrowali się wokół czterech wątków tematycznych:

- istoty dialogu edukacyjnego poszukiwali dr Maria Jagiełło i dr Jarosław Michalski;

- polskiego nauczyciela $\mathrm{w}$ dialogu edukacyjnym opisywały dr Monika Jurewicz, mgr Regina Nagadowska oraz dr Agnieszka Konieczna;

- dialog w specyficznych środowiskach edukacyjnych zauważali dr Anna Podemska-Kałuża, dr Tomasz Brzozowski i dr Ewa Lubina; 
- dialog w przestrzeniach akademickich obserwowały dr Elżbieta Okońska, dr Dorota Jankowska, dr Alicja Olszak, mgr Maria Lewandowska i mgr Magdalena Ostolska.

4) IV Sekcja, czyli panel dyskusyjny młodzieży licealnej i studentów I roku pedagogiki, zatytułowany Dialog w doświadczeniu uczniów szkót średnich i studentów, poprowadziły studentki IV roku pedagogiki kreatywności APS Zuzanna Doliwa i Dorota Olędzka przy wsparciu mgr Marleny GrzelakKlus. W burzliwej dyskusji udział wzięli: Kacper Aleksandruk, Marcjanna Błudzień, Paula Bobin, Anna Budzik, Jaromir Brehmer, Małgorzata Czarzasta, Michał Dębny, Aleksandra Falba, Angelika Ferenc, Adam Góral, Katarzyna Hefko, Magdalena Kasak, Natalia Łasica, Agnieszka Mazańska, Karolina Nowińska, Anna Piskorska, Paulina Roman, Jagoda Rosiak, Martyna Szafrańska, Katarzyna Śniegórska, Pamela Świdulska, Monika Wiśniewska, Anna Życka, to jest reprezentanci wrocławskiego Liceum Ogólnokształcącego ALA, reprezentanci warszawskiego Liceum Ogólnokształcącego XLVIII im. E. Dembowskiego, studenci I roku pedagogiki w APS oraz pani prof. dr hab. Joanna Rutkowiak i pan prof. dr hab. Bogusław Milerski.

Dialog młodych ludzi moderowany był z nastawieniem na wymianę własnych doświadczeń dialogowych w instytucjach edukacyjnych. Wystąpienia uczniów wrocławskiego Liceum Ogólnokształcącego ALA, przedstawiające idee i praktyki dialogowe związane z życiem uczniów i nauczycieli tejże szkoły, oraz wystąpienia studentów I roku pedagogiki, przedstawiające raport z badań dotyczących doświadczeń dialogowych uczniów warszawskich szkół średnich, prowokowały zebranych do wymiany własnych doświadczeń i przemyśleń związanych z dialogiem, odczuwaną potrzebą dialogowania czy też uwarunkowaniami sprzyjającymi i utrudniającymi prowadzenie tego typu relacji w obszarach edukacyjnych.

Przedstawiając wnioski płynące z obrad sekcji IV, uczniowie i studenci przypomnieli, że istotą dialogu jest człowiek, jego godność i szacunek do niego. Dialogowanie w szkole jest potrzebne, ale wymaga wysiłku i zaangażowania tak nauczycieli/wychowawców, jak i samych uczniów. Dialog rozwija i zmienia każdego, zwłaszcza ludzi młodych. Dojrzewają oni do odpowiedzialności za swoje decyzje i postępowanie, także w kontekstach szkolnych, za sprawą poznawania siebie, swoich możliwości i pragnień, $\mathrm{w}$ autentycznym kontakcie z drugim człowiekiem.

Podsumowując obrady na forum plenarnym, profesor Urszula Ostrowska pytała o możliwość uchwycenia i prostego ujęcia tak różnorodnych głosów i wystapień przedstawianych w konferencyjnych dyskusjach. Odpowiedzi udzieliła, zwracając uwagę na potrzebę kultywowania kultury dialogu tak w edukacji, jak i w polskim społeczeństwie XXI wieku. W tym sensie wydaje się, iż listopadowa czasoprzestrzeń, w której pedagodzy dialogu spo- 
tykają się i dialogują ze sobą, dialogują z młodymi ludźmi, którzy doświadczają edukacji i tej dialogowej, i tej niedialogowej oraz wskazują na swoje potrzeby w tej kwestii, a także dialoguja z młodymi ludźmi studiującymi pedagogikę i budującymi własną tożsamość pedagogiczną, przyczynia się do kultywowania owej kultury dialogu. I tak cykliczna Konferencja Pedagogiki Dialogu, przyczyniając się do budowania i wspierania akademickiej kultury dialogu i otwartej refleksji pedagogicznej, na stałe wpisuje się w terminarz listopadowych spotkań pedagogów dialogu.

Doceniając wkład pracy w przygotowanie i organizację III Ogólnopolskiej Konferencji Pedagogiki Dialogu, warto podziękować komitetowi organizacyjnemu Katedry Podstaw Pedagogiki Akademii Pedagogiki Specjalnej im. Marii Grzegorzewskiej w Warszawie, a przede wszystkim prof. dr. hab. Bogusławowi Milerskiemu, dr Dorocie Jankowskiej oraz dr Ewie Dąbrowie. 